\title{
D2-40 Immunoreactivity of Lymphatic Vessels Endothelium and Representation of Lymphatic Vessels in the Liver of Human Fetuses of Different Gestational Age
}

\author{
Marko Jović ${ }^{1}$, Ivan Nikolić ${ }^{1}$, Vera Todorović ${ }^{2}$, Aleksandar Petrović ${ }^{1}$, Vladimir Petrović ${ }^{1}$, \\ Tijana Denčić ${ }^{3}$ \\ ${ }^{1}$ University of Niš Faculty of Medicine, Department of Histology and Embryology, Niš, Serbia \\ ${ }^{2}$ University of Business Academy Novi Sad, Faculty of Stomatology Pančevo, Department of Histology and \\ Embryology, Serbia \\ ${ }^{3}$ University of Nis Faculty of Medicine, Center for Pathology and Pathological Anatomy, Niš, Serbia
}

SUMMARY

In the reference literature, there are a few studies on the development of the lymphatic system in the liver, especially human. This study aims to establish the presence, time of appearance, distribution and representation of expression D2-40 molecule - a marker of lymph vessels endothelial cells during the fetal period of the human liver development.

The livers obtained from 20 human fetuses (10 male and 12 female), aged 12-37 gestational weeks, constituted our study material. Paraffin sections, $4 \mu \mathrm{m}$ thick, were stained with hematoxylin and eosin for histological analysis, and with LSAB2/HRP method for immunohistochemistry using the D2-40 monoclonal antibody to mark lymphatic endothelial cells. The presence of lymphatic vessels was determined by morphometry, calculating their numerical and volume density.

The study showed that expression of D2-40 molecule was absent in the liver lymphatic vessels in the first trimester of development, while in the second trimester intensive D2-40 immunoreactivity was observed in the lymph vessels of the liver capsule, and low D2-40 immunopositivity of the lymph vessels in large portal spaces. In the third trimester, intensive D2-40 immunoreactivity was observed in the lymph vessels of the liver capsule and in the endothelium of numerous lymphatic vessels of various shape and size, located in the smaller and larger portal areas. Volume and numerical density of lymphatic vessels in the portal areas of the liver during fetal development increased from the second to the third trimester of pregnancy, which was proportional to the increase in volume density of the hepatic portal spaces. Based on the obtained results, a conclusion may be drawn that the lymph vessels in the liver can be identified in the first half of the second trimester, and their number was growing proportionally by the end of pregnancy.

Key words: D2-40 molecule, lymph vessels, liver, human fetus

Corresponding author:

Marko Jović

E-mail: marko.jovic@medfak.ni.ac.rs 


\section{INTRODUCTION}

The liver is formed out of the two germ layers: endoderm of the ventral side and distal end of the foregut, out of which the hepatic diverticulum will be created. Hepatocytes and epithelium of the smaller intrahepatic bile ducts will be created out of the cells of hepatic diverticulum. Connective tissue, blood and lymph vessels of the liver will originate from the surrounding septum transversum mesoderm $(1,2)$.

Portal - functional blood flow is established between gestational weeks 4 and 6, while the hepatic nutritional blood flow is established between 10 and 15 weeks of development. Liver sinusoids tend to appear very early, in gestational week 4, but their morphological, functional, and immunohistochemical characteristics are established gradually, up to gestational week 20 (3).

The lymphatic system of the liver plays an important role in the homeostasis of this organ, by collecting the excess interstitial fluids and protein metabolites of the liver, which are returning into the blood through the lymphatic vessels. One-third of the total lymph flow into the ductus thoracicus is produced in the liver. Lymph is first collected in the perisinusoidal areas, from where it flows into the Mall's lymph spaces localized between the periportal hepatocyte border membrane and connective tissue of portal spaces. From these areas, lymph flows into the lymphatic vessels of the connective portal area tissue. In relation to their position, lymph vessels of the liver are forming three splices: periportal, sublobular and capsular which flow into the ductus thoracicus. Lymphatic vessels, on cross section, in the portal tracts have irregular thin wall, often of wriggly shape (4).

The development of lymph vessels has not yet been fully elucidated, and the propositions presented so far are based mainly on experimental work with animal embryos and fetuses. Two theories have been proposed to explain the lymph vessel formation (5). According to the so called "cetrifugal theory" by Sabin, the "primitive" lymph sac develops from the endothelial cells of the cardinal vein bud, which precedes the formation of lymphatic vessels, which is formed out of endothelial cells of bud cardinal vein, from where lymphatic endothelial cells migrate towards the periphery, at $7^{\text {th }}$ week of intrauterine development. The other is the "centripetal theory" by George Huntington and Charles McCure, according to which endothelial cells of lymph vessels are formed according to the model of vasculogenesis, when the groups of mesenchymal cells are formed, wherein the peripheral mesenchymal cells are transformed into endothelial cells of the lymph vessels (5).

Identification of lymphatic endothelial cells is possible owing to the implementation of specific endothelial markers. Different markers are expressed on the surface of these cells, such as: Prox-1 (Prospero homeobox protein 1), D2-40, LYVE-1 (Lymphatic Vessel Endothelial Receptor 1), VEGF (Vascular Endothelial Growth Factor), plakoglobin and integrin alpha-9. Prox-1 is a specific marker of a subpopulation of endothelial cells which generates the lymphatic system of mammals. The mammals which lack Prox-1 molecule do not have a developed lymphatic system, whereas the processes of vasculogenesis and angiogenesis are normally carried out, which indicates that this molecule is exclusively connected with lymphangiogenesis (6). Plakoglobin or gamma-catenin is a member of the catenin family of proteins, and it constitutes desmosomes and adherent cell connections. Its function is to connect the cytoplasmic part of cadherin with the actin cytoskeleton of the cells. Plakoglobin is expressed on both the vascular and lymphatic endothelial cells. Unlike plakoglobin, integrin alpha-9 is exclusively expressed on endothelial cells of lymphatic vessels, and its role is to connect the cells with the extracellular matrix proteins, osteopontin and tenascin (7). LYVE-1 is a transmembrane protein, identified primarily on the endothelial cells of lymph vessels in a lymph node $(8,9)$, and is defined as the main receptor for hyaluronic acid. It is nowadays used as a marker of lymph vessels $(10,11)$ and lymphangiogenesis (12). D2-40 antibody reacts with podoplanin - a cell membrane protein, the expression of which has been confirmed on the endothelial cells of lymph vessels in various normal tissues, but also in vascular tumors and in some tumors of non-vascular origin (13).

Bearing in mind the fact that the development of lymph vessels in the human liver has been scarcely described in the literature so far (14), this study attempted to establish the existence of D2-40 molecules, lymphatic endothelial cell markers, providing thus an insight into the time of appearance, level of immunoreactivity, distribution and localization of lymph vessels during fetal development of the human liver.

\section{MATERIAL AND METHODS}

The study was performed on 22 livers from human fetuses (10 male and 12 female), aged 12-40 gestational weeks. The fetuses were taken from the 
Clinic of Gynecology and Obstetrics, Clinical Center Niš (after a spontaneous or artificial abortion), and then autopsied at the Center for Pathology and Pathological Anatomy, Clinical Center Niš, with a prior approval of the Ethics Committee of the Faculty of Medicine in Niš (№ 12-2307-2/9). The parameters for fetal age calculations were determined according to the Carnegie stage system (15). The livers of the fetuses were without macroscopically visible damage.

The samples of fetal livers were fixated in $4 \%$ buffered formaldehyde for 24-48 hours and routinelly processed all the way to the paraffin blocks. Using a microtome Leica RM2255 (Leica Micro-Systems, Reuil-Malmaison, France), $4 \mu \mathrm{m}$ thick tissue sections were made, stained with hematoxylin and eosin $(\mathrm{H}-$ E), for the analysis of histological structure of the liver. To prove antigen D2-40, LSAB2/HRP immunohistochemistry assay was used.

Immunohistochemistry approach consisted of the following procedures: exposure of tissue samples to $0.01 \mathrm{M}$ citrate buffer ( $\mathrm{pH}$ 6.0) in a water bath at 95$98^{\circ} \mathrm{C}$ for 20 minutes, endogenous peroxidase blocking with 3\% solution of hydrogen peroxide for 10 minutes at room temperature, and phosphate buffer washing of the sections $(0.02 \mathrm{M}, \mathrm{pH}$ 7.0; Code S3024, Denmark), for three times, 2 minutes each. The incubation with primary antibody D2-40 (Dako, M3619, dilution 1:150 with antibody diluent, Code S0809, Dako) was performed in a moist chamber at the temperature of $4^{\circ} \mathrm{C}$ overnight. The LSAB2 SystemHRP (Code K0673, Dako, USA) was used for visualization, and Mayer's hematoxylin for contrast enhancement. After a dehydration in alcohol and purification in xylol, the sections were mounted in Canada-balsam.

Intensity of D2-40 immunohistochemical reaction on analyzed samples was shown by semiquantitative analysis (-, absent; -/+, very low; ++,

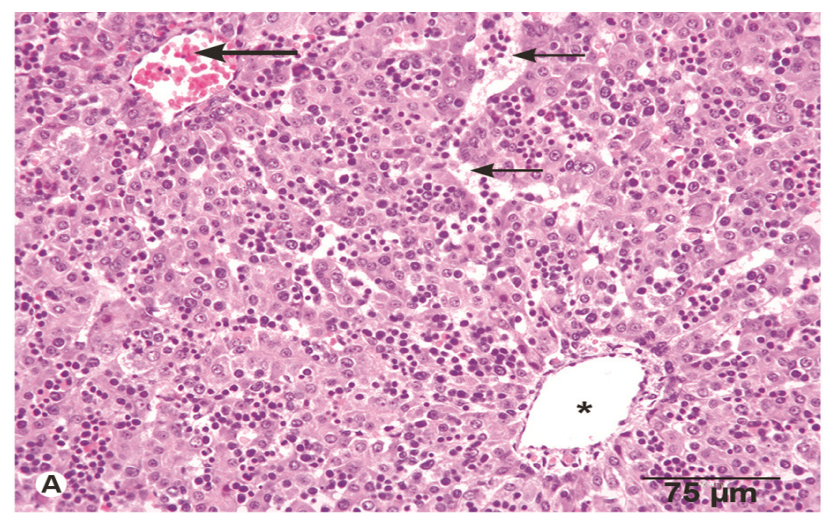

medium; +++, high). Microphotographs of the histological samples were obtained by taking photos of the tissue sections on a light microscope (Olympus BX-50) equipped with a Leica DFC 295 digital camera (Leica Micro-Systems, Reuil-Malmaison, France). To determine the presence of lymphatic vessels were used the morphometric methods for calculating the volume density of liver portal areas and numerical and volume density of lymphatic vessels of portal areas, with the help of the program ImageJ on the appropriate number of visual fields (40 per trimester for the volume density of hepatic portal areas, and 10 per trimester for calculating the volume and the numerical density of lymphatic vessels of portal areas).

\section{RESULTS}

Histological characteristics of liver and D240 immunoreactivity in the first trimester of fetal development

Histological structure of liver in the first trimester does not have a clearly defined lobular structure. In the embryonic period, after the sixth week of development, expanded vascular spaces in the liver can be observed that correspond to immature portal branches, central veins and sinusoids, which are usually surrounded by multi-layered and irregularly oriented bands of hepatocytes. At the beginning of fetal period in the liver, immature portal areas (include arterial and venous branches, but not bile ducts), central venules, slightly expanded sinusoids and hematopoiesis islets could be distinguished (Figure 1A).

By the end of the second trimester, D2-40 immunoreactivity is not identified in any structure of the liver (Figure 1B, Table 1).

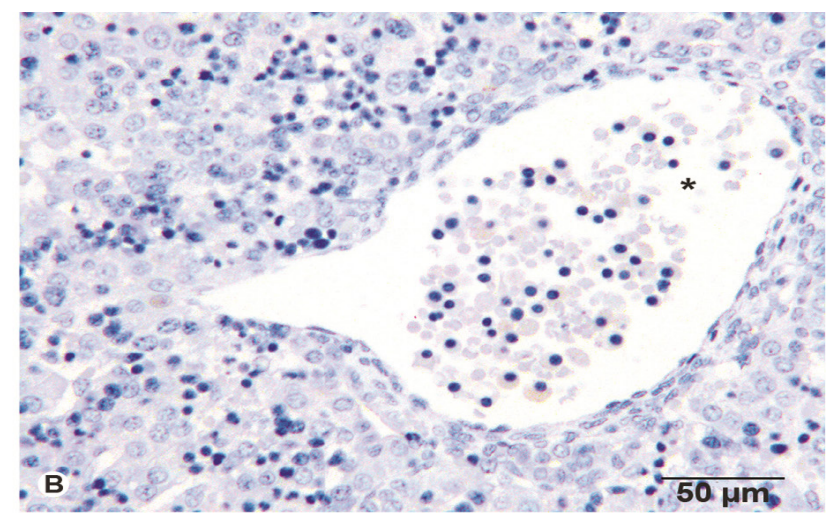

Figure 1. The liver of the fetus in the first trimester. A - Histological structure of the fetal liver in the first trimester: irregular shape of sinusoids (thin arrows), central vein (thick arrow), immature portal areas (asterisk) (HE, x250); B - portal area does not contain D2-40 immunoreactive cells (LSAB2 / HRP, x 400). 



\section{Histological characteristics of liver and} D2-40 immunoreactivity in the second trimester of fetal development

In the second trimester, the histological structure of fetal liver indicates a slightly more pronounced lobular structure. The portal areas are complete (containing all the elements of portal triad), and within them, especially within the large ones, branched blood-vessel system is noticed (Figure 2A).
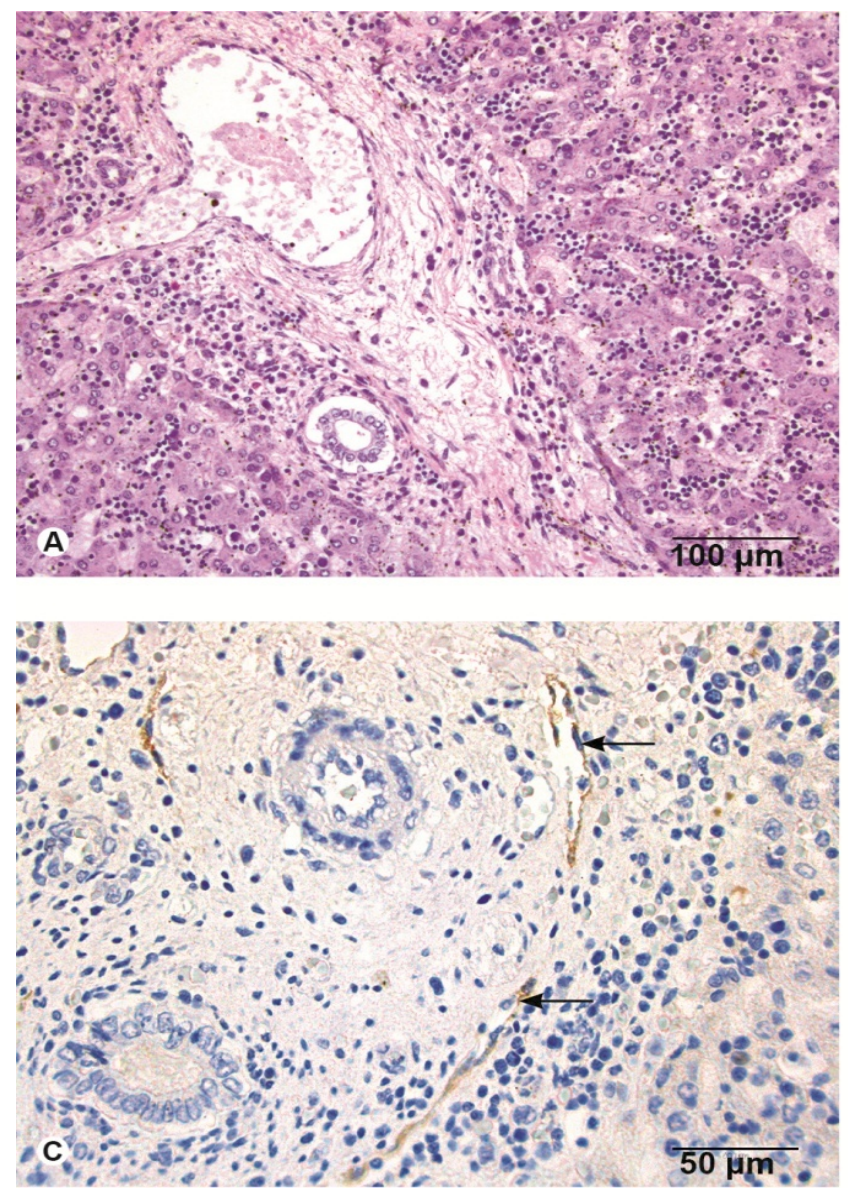

Central veins are recognizable, sinusoids are narrower. Hematopoiesis is extremely present in the liver during this period.

Intensive D2-40 immunoreactivity can be seen in the lymph vessels of the capsule (Figure 2B, table 1). Low D2-40 immunopositivity can be observed in larger portal tracts, in the lymphatic vessels with narrow lumen (Figure 2C, Table 1). In small portal tracts, D2-40 is not expressed in any of the structures (Figure 2D).
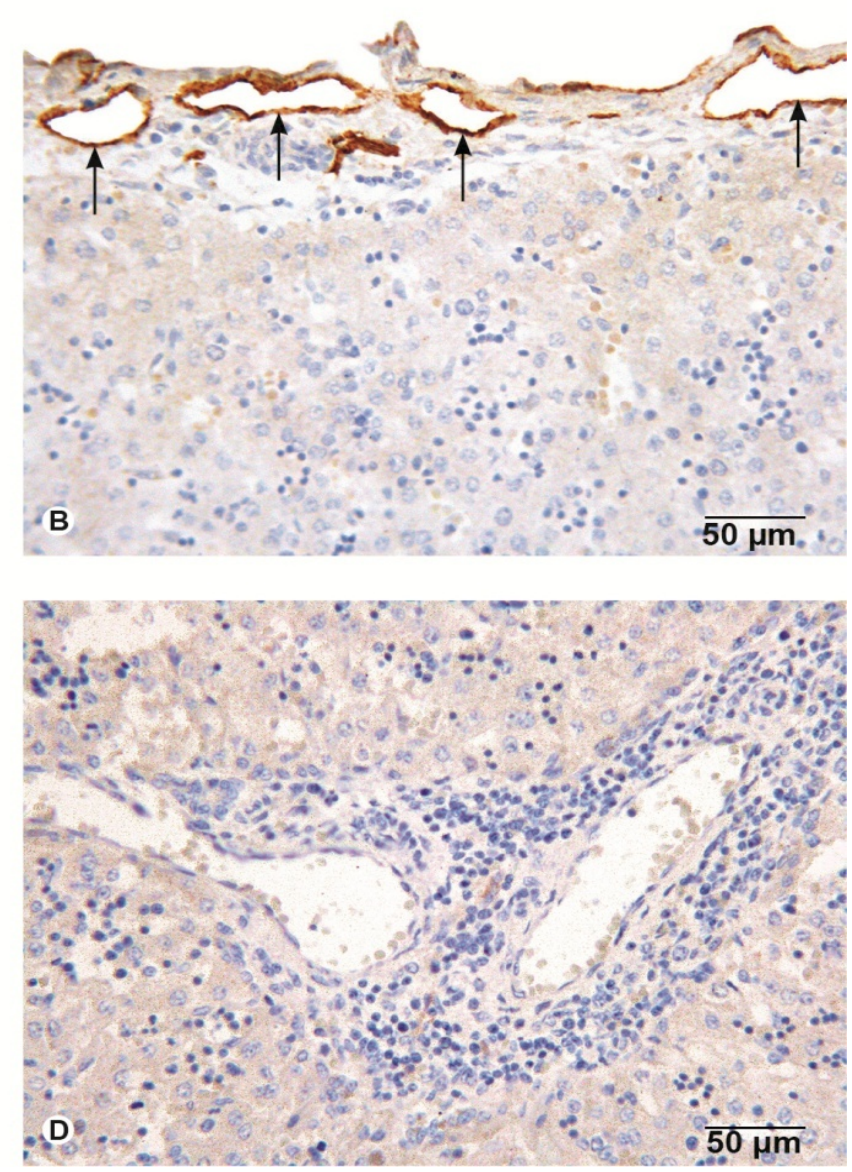

Figure 2. The fetal liver in the second trimester. A - portal area and part of the liver parenchyma (HE, x200); B - Numerous lymphatic vessels with intense D2-40 endothelium in a capsule (thin arrows) (LSAB2 / HRP, x320); C - largerr portal area with moderate D2-40 immunoreactive endothelium in the lymph vessels of elongated shape (thin arrows) (LSAB2 / HRP, x400); D - in a small portal area D2-40 immunoreactivity is not identified (LSAB2 / HRP, x320).

\section{Histological characteristics of liver and D2-40 immunoreactivity in the third trimester of fetal development}

In the process of further development, all the structural components become recognizable - the liver acquires the appearance of an almost adult organ, with hepatocytes organized into single-layer or bilayer bands between which there are regular-shaped, small-lumen sinusoids, central venules are clearly recognizable, and the connective tissue of portal spaces then becomes well defined with presence of larger or smaller number of 
blood vessels and bile ducts (Figure 3A). Islets of hematopoiesis are less pronounced in comparison to the previous period. Intensive D2-40 immunoreactivity is observed in the lymph vessels of the liver capsule (Figure 3B, Table 1), as well as in both larger (Figure 3C)
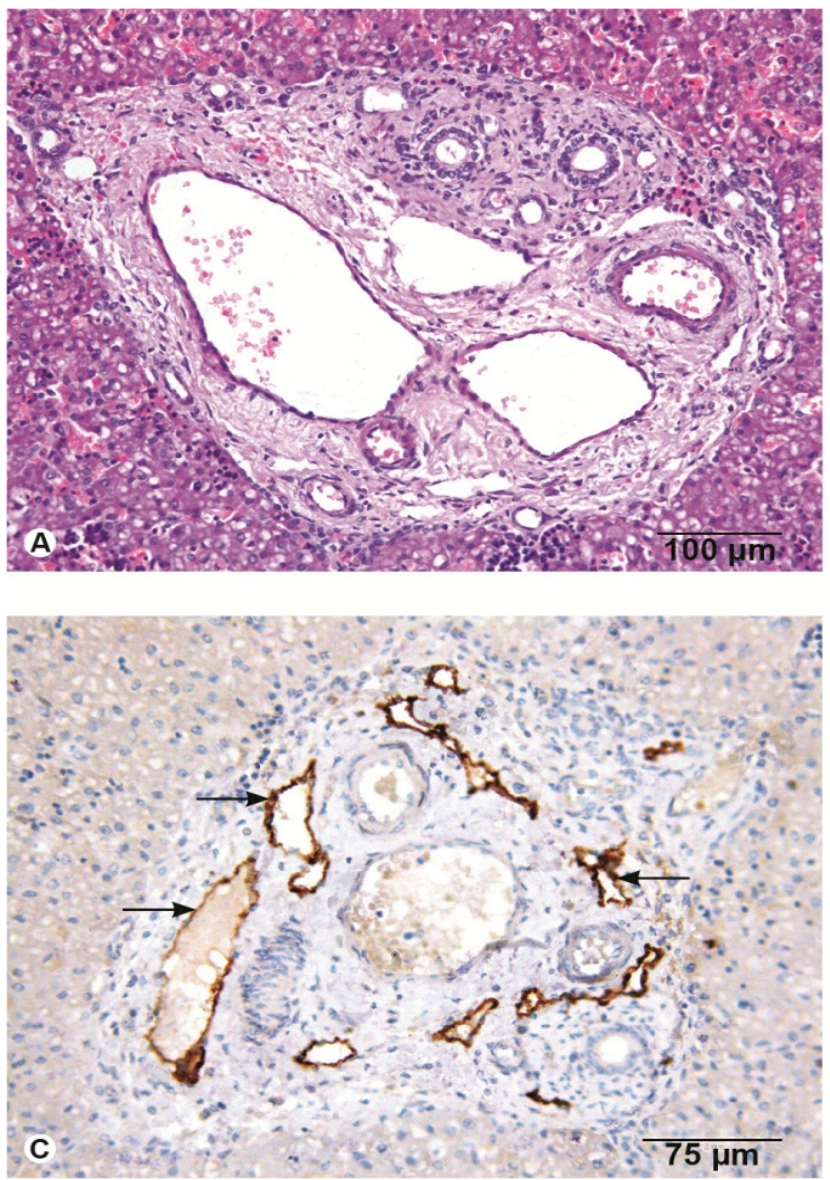

and smaller (Figure 3D) portal tracts, in the endothelium of lymphatic vessels of many different shapes and sizes (Table 1). During this period of development, a slightly larger number of lymph vessels are located near interlobular arteries and their branches.
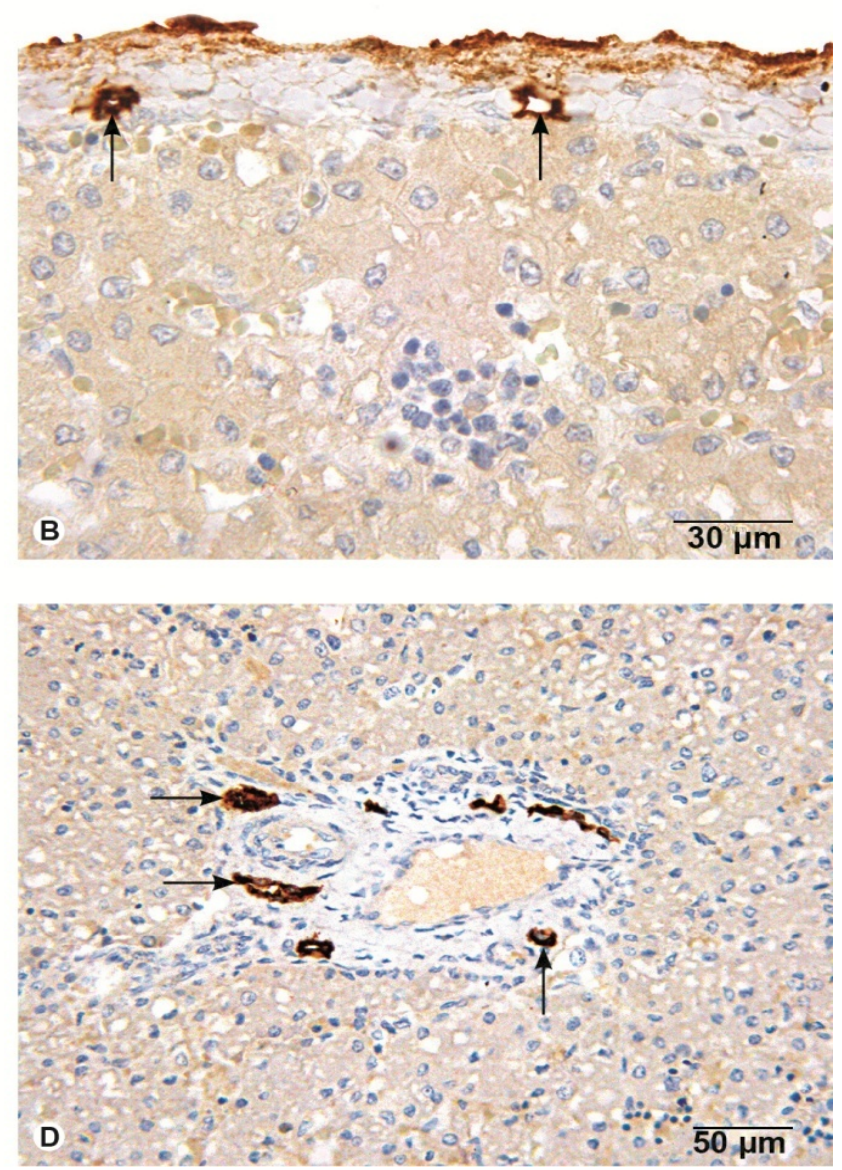

Figure 3. The fetal liver in the third trimester. A - portal area with the surrounding liver parenchyma of the fetus in the third trimester (HE, x200); B - lymph vessels with intense D2-40 immunoreactive endothelium in a capsule (thin arrows) (LSAB2/HRP, x640); $\mathrm{C}$ - large portal area contains numerous lymph vessels of different shapes and sizes, with D2-40 positive endothelium (thin arrows) (LSAB2/HRP, x250); D lymphatic vessels with intense D2-40 positive endothelium are present even in the connective tissue of the smallest portal areas (thin arrows) (LSAB2/HRP, x320).

Table 1. D2-40 immunoreactivity in endothelial cells of sinusoids and lymphatic vessels of the fetal human liver

\begin{tabular}{c|c|c}
\hline \hline \multirow{2}{*}{ Age } & \multicolumn{2}{|c}{ Immunoreactivity } \\
\cline { 2 - 3 } & Endothelium & D2-40 \\
\hline \multirow{2}{*}{ I trimester } & Lymphatic vessels of liver capsule & - \\
\cline { 2 - 3 } & Lymphatic vessels of liver portal area & - \\
\hline \multirow{2}{*}{ II trimester } & Lymphatic vessels of liver capsule & ++ \\
\cline { 2 - 3 } & Lymphatic vessels of liver portal area & ++ \\
\hline \multirow{2}{*}{ III trimester } & Lymphatic vessels of liver capsule & +++ \\
\cline { 2 - 3 } & Lymphatic vessels of liver portal area & +++ \\
\hline \hline
\end{tabular}

Intensity of immunochemical staining: absent,-; very low,-/+; low,+; medium,++; high,+++. 


\section{Morphometric characteristics of the liver} during fetal period

The volume density of lymphatic vessels in the portal areas of the liver during fetal development increases from the second to the third trimester of pregnancy (Graph 1), which is proportional to the increase in volume density of portal areas (Graph 2). Numerical density of lymphatic vessels in the liver portal tracts also follows the trend of increasing from the second to the third trimester of fetal development (Graph 3). The volume density of lym- phatic vessels in the liver portal tracts in the second trimester, expressed in percentages, is $7.516 \pm 1.91$, and in the third trimester is $12.23 \pm 3.22$ (Graph 1). The volume density of portal areas in the first trimester, expressed in percentages, is $5.3 \pm 3.92$, in the second trimester is $12: 45 \pm 6.19$, and in the third trimester $18.77 \pm 13.05$ (Graph 2).

Numerical density of lymphatic vessels in the portal tracts in the second trimester is $7.454 \pm 2.77$, while in third is $15.48 \pm 2.52$ (Graph 3), which is significantly higher in comparison to the second trimester.

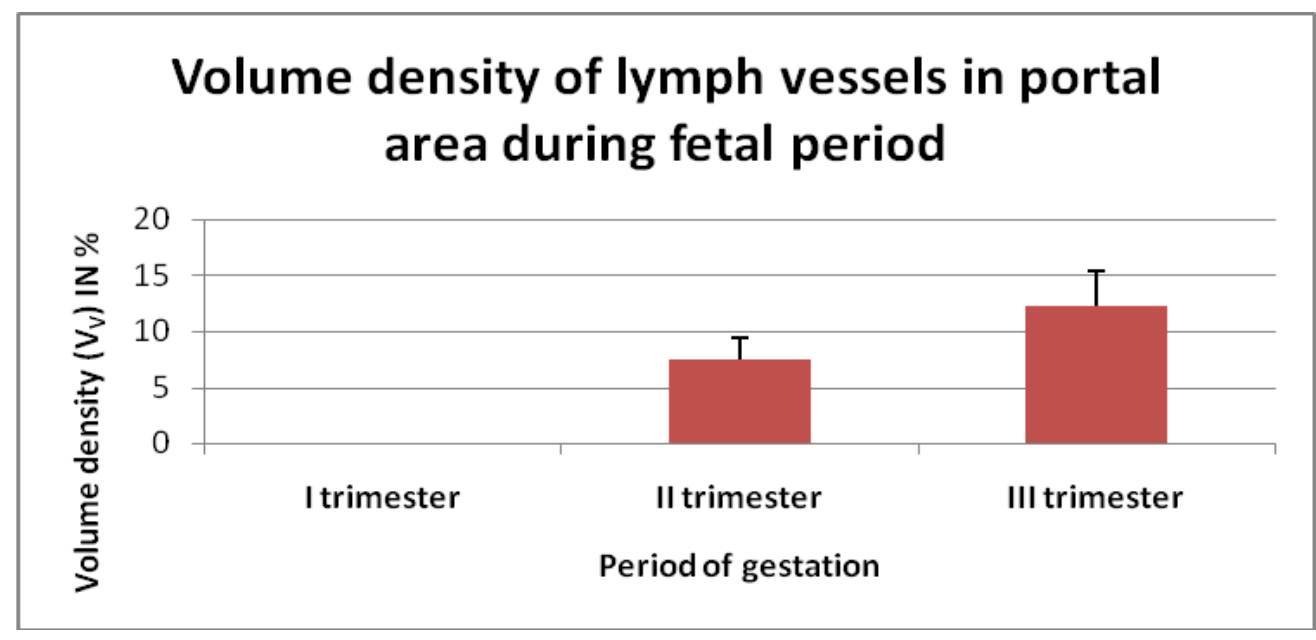

Graph 1. The volume density of lymphatic vessels in the portal areas of the liver during the fetal period of development $(\mathrm{p}<0.01)$

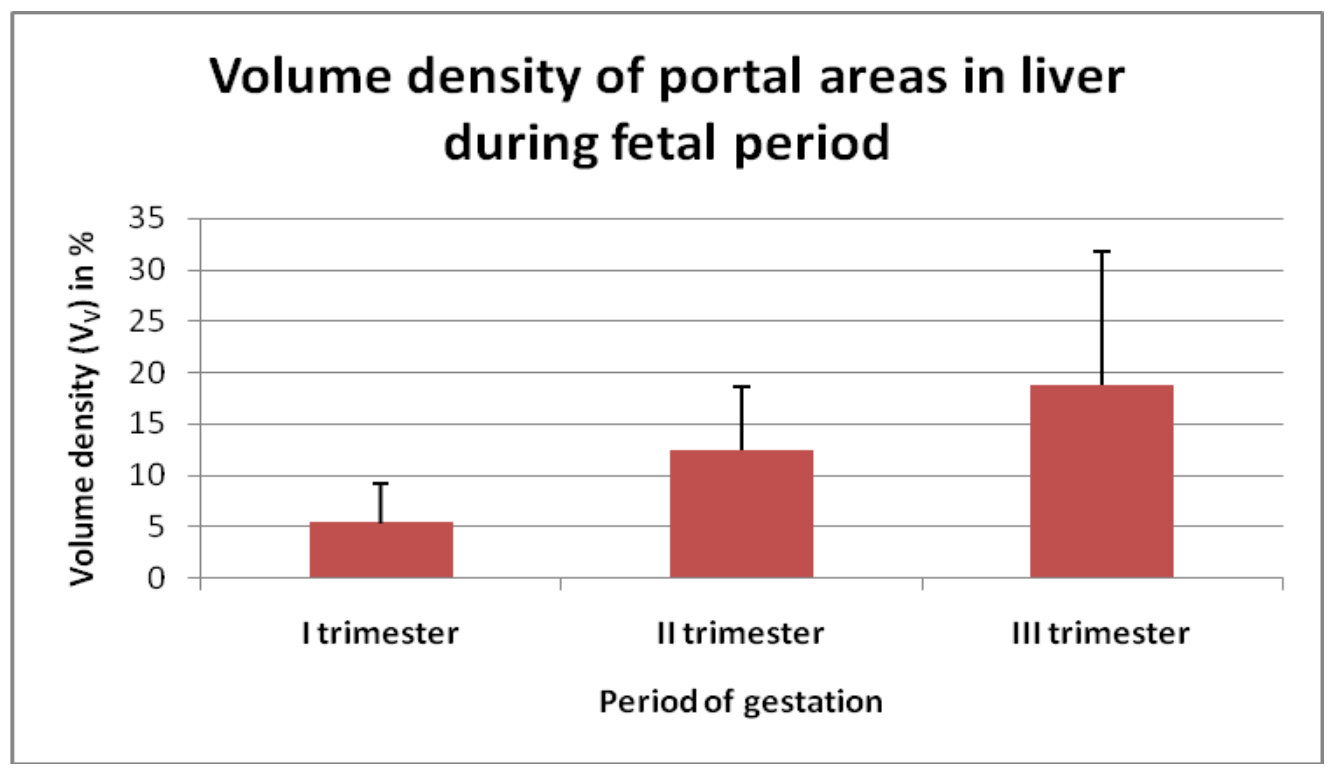

Graph 2. The volume density of portal areas in liver during the fetal period of development $(p<0.01)$ 


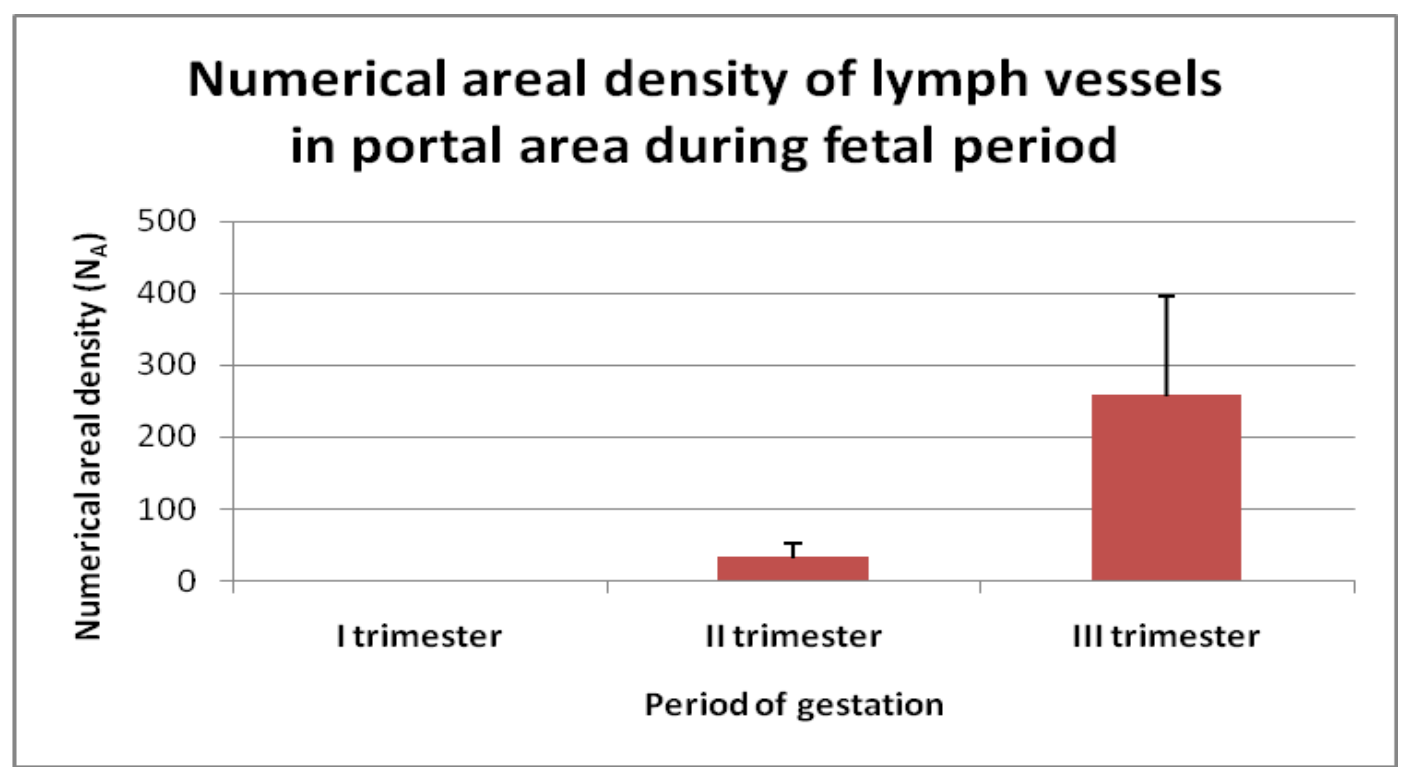

Graph 3. Numerical density of lymphatic vessels in the portal areas of the liver during the fetal period of development $(\mathrm{p}<0.01)$

\section{DISCUSSION}

Endothelium is a common structural component of lymph vessels and sinusoids of the liver, but during embryonal development it differentiates into two morphologically and functionally different epithelial lines characterized by the expression of different molecules - endothelial cells in the liver sinusoids express, above all, CD31 and CD34 molecules (16, 17), while endothelial cells of the lymph vessels express LYVE-1 $(8,18,19)$ and D2-40 molecules $(20,21)$.

The results of this study show that first appears D2-40 immunoreactivity in the endothelium of lymphatic vessels of the liver capsule in the second trimester, starting from the $15^{\text {th }}$ week of development. This finding corresponds with the results of $\mathrm{Wu}$ Jin et al., which pointed out that in the period of 18 weeks of gestation, lymph vessels in the connective tissue capsule and hilum appear in the liver (22).

The finding that the lymphatic endothelium with D2-40 positive cells was first identified in the capsule supports the existence of capsular lymphatic plexus, which is the most probably formed the earliest.

In portal areas, especially larger and hilar ones, a weak to moderate D2-40 immunoreactivity was identified in endothelial cells of a few lymph vessels.

Our findings in the liver of the fetus in the third trimester of pregnancy indicate that the intensive D2-40 immunoreactivity in the endothelium of lymphatic vessels occurs in the capsules and in the connective tissues of both the largest and the smallest portal areas. The distribution of lymphatic vessels which is close to arterial branches indicates that periportal lymphatic plexus could be formed in this period of liver development (4).

The increase in intensity of D2-40 immunoreactivity on endothelial cells, proportionately to the age of the fetus, both in the capsule and the portal tracts, may point to maturing of lymphatic endothelial cells that undergo differentiation process, from immature (little or absent D2-40 antigen expressed) to mature, where D2-40 expression was intense. In support of this finding is the fact that the expression of LYVE-1 molecule, a marker of endothelial cells of lymphatic vessels, gradually increases during the period of fetal development, which confirms the fact of the differentiation of lymphatic endothelial cells $(1,17,23$, 24). It should be noticed that in the liver tissue in the first trimester of development, non-differentiated mesenchymal stellate cells were seen around the structures in portal spaces expressing LYVE-1 and morphologically corresponding to lymph vessels $(1,18$, $24,25)$. Considering this finding together with the assumption that LYVE-1 is the main known receptor for hyaluronic acid (18), with a role in hyaluronic acid transport from the tissue to the lymph (10), we suppose that the first lymph vessels in the liver are created from the mesenchymal cells in the region of portal spaces after 
the portal triad formation, while the main lymph trunk originates from the lymphatic sac, i.e. from the endothelial bud of the cardinal vein (21).

A stronger expression of D2-40 in tissue samples at 37 weeks of gestation suggests the role of podoplanin, a receptor for D2-40, in the definitive phenotypic differentiation of lymphatic endothelial cells. Moreover, it should be stressed that our result about the distribution of D2-40 in the liver at the end of fetal period matches its distribution in the hepatic tissue in adults (17). Recently, utilizing D2-40 on the samples of adult hepatic tissue, Fujii et al. (20) have documented podoplanin expression in the lymphatic endothelium, nerve fibers, and mesothelium covering the fibrous capsule and, at the same time, an absence of its expression in any of the cell populations in the liver lobule.

As far as the morphometric findings are concerned, the paper shows regularity in relation to the total volume of the portal areas of the liver and the total volume and number of lymphatic vessels, due to the fact that these three parameters increase with the age of the fetus. Yamauchi et al. showed the volume and numerical density of lymphatic vessels in the portal areas of the adult liver, which corresponds to our results on morphometric characteristics of the fetal liver in the third trimester of development (26).

In the last decade, numerous biological factors have been identified with possible roles in the control of development of the lymphatic system in general; in addition to LYVE-1, vascular endothelial growth factor (VEGF) and bone morphogenetic protein (BMP) were suggested to play an important role, and from 9 to 15 weeks of gestation the transcription factor Prox 1 and podoplanin may be added to this list $(5,21)$.

In addition to the use of D2-40 molecule as a marker of endothelial cells in lymph vessels, there has been evidence of the expression of its receptor podoplaninin certain tumors of the liver as well (hemangioma, epithelioid hemangioendothelioma), so that D2-40 molecule, that binds to podoplanin, in addition to being adopted as a marker of lymph vessel endothelium, can be used as a diagnostic marker for epithelioid hemangioendotheliomas in the liver (20).

\section{CONCLUSION}

D2-40 immunoreactivity was identified in endothelial cells of lymphatic vessels of the liver in the second trimester of pregnancy, starting at the $15^{\text {th }}$ week of development, primarily in the capsule, and then in the portal tracts. The level of immunereactivity in lymphatic endothelium and presence of lymphatic vessels increase with maturation of the liver, till the end of the fetal period of development.

\section{Acknowledgments}

This study was supported by grants from the scientific projects number 175061 and 175015 Ministry of Education, Science and Technological Development of the Republic of Serbia and by grant from the internal project number 22 of Faculty of Medicine University of Niš, Serbia. Authors do not have any conflict of interest in this article. 


\section{References}

1. Zorn AM. Liver development. 2008 Oct 31. In: StemBook [Internet]. Cambridge (MA): Harvard Stem Cell Institute; 2008-. Available from: https://www.ncbi.nlm.nih.gov /books/NBK27068/ doi: 10.3824/stembook.1.25.1 https://doi.org/10.3824/stembook.1.25.1

2. Si-Tayeb K, Lemaigre FP, Duncan SA. Organogenesis and development of liver. Developmental Cell 2010; 18: 175-89. https://doi.org/10.1016/j.devcel.2010.01.011

3. Collardeau-Frachon S, Scoazes JY. Vascular development and differentiation during human liver organogenesis. The Anatomical Record 2008; 291: 614-27.

https://doi.org/10.1002/ar.20679

4. Ohtani O, Ohtani Y. Lymph circulation in the liver. The Anatomical Record 2008; 291: 643-52. https://doi.org/10.1002/ar.20681

5. Semo J, Nicenboim J, Yaniv K. Development of lymphatic system: new questions and paradigms. Development 2016; 143: 924-35. https://doi.org/10.1242/dev.132431

6. Wigle J, Oliver G. Prox1 function is required for the development of the murine lymphatic system. Cell. 1999; 98:769-78.

https://doi.org/10.1016/S0092-8674(00)81511-1

7. Petrova TV, Makinen T, Makela TPet al. Lymphatic endothelial reprogramming of vascular endothelial cells by Prox-1 homeobox transcription factor. EMBO J. 2002; 21:4593-9. https://doi.org/10.1093/emboj/cdf470

8. Banerji S, Ni J, Wang S et al. LYVE-1, a New Homologue of the CD44 Glycoprotein, Is a Lymph-specific Receptor for Hyaluronan JCB 1999; 144:789-801.
9. Wrobel T, Dziegiel P, Mazur G et al.. LYVE1expression on high endothelial venules (HEVs) of lymph nodes. Lymphology 2005; 38:107-10.

10. Prevo R, Banerji S, Ferguson DJ et al. Mouse LYVE-1 is an endocytic receptor for hyaluronan in lymphatic endothelium. J Biol Chem. 2001; 276:19420-30.

https://doi.org/10.1074/jbc.M011004200

11. Jackson DG. The lymphatics revisited: new perspectives from the hyaluronan receptor LYVE-1. Trends Cardiovasc Med 2003; 13:1-7. https://doi.org/10.1016/S1050-1738(02)00189-5

12. Gale WN, Prevo R, Espinosa J et al.. Normal Lymphatic Development and Function in Mice Deficient for the Lymphatic Hyaluronan Receptor LYVE-1. Mol Cell Biol January 2007; 27: 595-604.

https://doi.org/10.1128/MCB.01503-06

13. Pusztaszeri MP, Seelentag W, Bosman FT. Immunohistochemical expression of endothelial markers CD31, CD34, von Willebrand factor, and Fli-1 in normal human tissues. $\mathrm{J}$ of Histochem Cytochem 2006; 54: 385-95. https://doi.org/10.1369/jhc.4A6514.2005

14. Butler MG, Isogai S, Weinstein BM. Lymphatic development. Birth defects research Part C, Embryo today: reviews. 2009; 87:222-31. https://doi.org/10.1002/bdrc.20155

15. O'Rahully R, Muller F. Developmental stages in human embryos. Carnegie Institution of Washington, Carnegie Laboratories of Embryology, California Primate Research Center and Departments of Human Anatomy and Neurology, University of California, Davis, 1987.

16. Abe S, Suzuki M, Ho Cho K et al. CD34-positive developing vessels and other structures in human fetuses: an immunohistochemical study. Surg Radiol Anat 2011; 33: 919-27. https://doi.org/10.1007/s00276-011-0854-2 
17. Nikolić I, Todorović V, Petrović A, Petrović V, Jović $M$, Vladičić J, Puškaš N. Immunohistochemical heterogeneity of endothelium of blood and lymphatic vessels in human liver in development and adulthood. 2016. DOI: $10.1159 / 000452214$

https://doi.org/10.1159/000452214

18. Carreira MC, Nasser MS, Di Tomaso E et al. LYVE-1 is not restricted to the Lymph vessels: expression in normal liver blood sinusoids and down-regulation in human liver cancer and cirrhosis. Cancer Research 2001; 61: 8079-84 .

19. Xu H, Edwards JR, Espinosa O et al. Expression of a lymphatic endothelial cell marker in benign and malignant vascular tumors. Human Pathol 2004; 35: 857-61.

https://doi.org/10.1016/j.humpath.2004.02.009

20. Fujii T, Zen $Y$, Sato $Y$ et al.. Podoplanin is a useful diagnostic marker for epithelioid hemangioendothelioma of the liver. Modern Pathology 2008; 21:125-30; doi: 10.1038/modpathol. 3800986

21. Jurisic G, Detmar M. Lymphatic endothelium in health and disease. Cell Tissue Res 2009; 335: 97108.

https://doi.org/10.1007/s00441-008-0644-2

22. Zhe Wu Jin,1 Takuo Nakamura, et al.. Fetal anatomy of peripheral lymphatic vessels: a D240 immunohistochemical study using an 18week human fetus (CRL $155 \mathrm{~mm}$ ). J. Anat. 2010; 21: 6671-68.

23. Gordon EJ, Gale NW, Harvey NL. Expression of the hyaluronan receptor LYVE-1 is not restricted to the lymphatic vasculature; LYVE-1 is also expressed on embryonic blood vessels. Dev Dyn. 2008; 237:1901-9. https://doi.org/10.1002/dvdy.21605

24. Arimoto J, Ikura Y, Suekane T, Nakagawa M, Kitabayashi C, Iwasa Y, Sugioka K, Naruko T, Arakawa T, Ueda M. Expression of LYVE-1 in sinusoidal endothelium is reduced in chronically inflamed human livers. J Gastroenterol. 2010; 45(3):317-25. https://doi.org/10.1007/s00535-009-0152-5

25. Banerji S, Ni J, Wang SX et al. LYVE-1, a new homologue of the CD44 glycoprotein, is a lymph-specific receptor for hyaluronan. J Cell Biol. 1999; 144:789-801. https://doi.org/10.1083/jcb.144.4.789

26. Yamauchi Y, Michitaka K, Onji M. Morphometric analysis of lymphatic and blood vessels in human chronic viral liver diseases. Am J Pathol. 1998; 153:1131-7. https://doi.org/10.1016/S0002-9440(10)65657-X 


\title{
D2-40 imunoreaktivnost endotela limfnih sudova i zastupljenost limfnih sudova u jetri humanih fetusa različite starosti
}

\author{
Marko Jović ${ }^{1}$, Ivan Nikolić1, Vera Todorović ${ }^{2}$ Aleksandar Petrović ${ }^{1}$, Vladimir Petrović1, \\ Tijana Denčićs \\ ${ }^{1}$ Univerzitet u Nišu, Medicinski fakultet, Katedra za histologiju i embriologiju, Srbija \\ ${ }_{2}^{2}$ Univerzitet Privredna akademija, Stomatološki fakultet u Pančevu, Katedra za histologiju i embriologiju, \\ Novi Sad, Srbija \\ ${ }_{3}^{3}$ Univerzitet u Nišu, Medicinski fakultet, Katedra za patologiju, Srbija
}

\section{SAŽETAK}

U literaturi postoje malobrojni podaci o razvoju limfnih sudova u jetri, naročito čoveka. Postavljen je cilj da se odredi postojanje, vreme pojavljivanja, distribucija i zastupljenost ekspresije D2-40 molekula arkera endotelnih ćelija limfnih sudova tokom fetusnog perioda razvića jetre čoveka.

Materijal su činile jetre 22 humana fetusa (10 muškog i 12 ženskog pola), starosti 12 - 37 nedelja gestacije. Parafinski preseci debljine $4 \mu \mathrm{m}$ bojeni su hematoksilinom i eozinom, za histološku analizu, i imunohistohemijskom LSAB2/HRP metodom, uz upotrebu monoklonskog antitela D2-40, za markiranje endotelnih ćelija limfnih sudova. Zastupljenost limfnih sudova je određivana morfometrijski, izračunavanjem njihove volumenske i numeričke gustine.

Rezultati pokazuju da se u limfnim sudovima jetre u I trimestru razvoja ne uočava D2-40 imunoreaktivnost, dok se $\mathbf{u}$ II trimestru uočava intenzivna D2-40 imunoreaktivnost $\mathbf{u}$ limfnim sudovima kapsule, a D2-40 imunopozitivnost slabog stepena u limfnim sudovima većih portnih prostora. U III trimestru intenzivna D2-40 imunoreaktivnost se uočava u limfnim sudovima kapsule jetre, kao i u endotelu brojnih limfnih sudova različitog oblika $i$ veličine $u$ manjim $i$ većim portnim prostorima. Volumenska $i$ numerička gustina limfnih sudova u portnim prostorima jetre za vreme fetalnog razvoja se povećava od II prema III trimestru trudnoće, što je srazmerno povećanju volumenske gustine portnih prostora.

Na osnovu iznesenih rezultata može se zaključiti da se limfni sudovi pojavljuju u prvoj polovini II trimestra i da je njihov broj raste, proporcionalno starosti jetre, do kraja trudnoće.

Ključne reči: D2-40 molekul, limfni sudovi, jetra, humani fetus 